\title{
Autochthonous West Nile virus infection outbreak in humans, Leipzig, Germany, August to September 2020
}

Corinna Pietsch ${ }^{1}$, Dominik Michalski ${ }^{2}$, Johannes Münch ${ }^{3}$, Sirak Petros ${ }^{4}$, Sandra Bergs ${ }^{1}$, Henning Trawinski ${ }^{5}$, Christoph

Lübbert ${ }^{5}$, Uwe G Liebert ${ }^{1}$

1. Institute of Virology, Leipzig University Hospital, Leipzig, Germany; Interdisciplinary Centre for Infectious Diseases, Leipzig University Hospital, Leipzig, Germany

2. Department of Neurology, Leipzig University Hospital, Leipzig, Germany

3. Division of Nephrology, Department of Endocrinology, Nephrology and Rheumatology, Leipzig University Hospital, Leipzig, Germany

4. Medical ICU, Leipzig University Hospital, Leipzig, Germany

5. Division of Infectious Diseases and Tropical Medicine, Department of Medicine II, Leipzig University Hospital, Leipzig, Germany; Interdisciplinary Centre for Infectious Diseases, Leipzig University Hospital, Leipzig, Germany

Correspondence: Corinna Pietsch (corinna.pietsch@medizin.uni-leipzig.de)

Citation style for this article:

Pietsch Corinna, Michalski Dominik, Münch Johannes, Petros Sirak, Bergs Sandra, Trawinski Henning, Lübbert Christoph, Liebert Uwe G. Autochthonous West Nile virus infection outbreak in humans, Leipzig, Germany, August to September 2020. Euro Surveill. 2020;25(46):pii=2001786. https://doi.org/10.2807/1560-7917. ES.2020.25.46.2001786

Article submitted on 14 Oct 2020 / accepted on 18 Nov 2020 / published on 19 Nov 2020

Following a distinct summer heat wave, nine autochthonous cases of West Nile fever and West Nile neuroinvasive disease, including one fatality, were observed in Leipzig, Germany, in August and September 2020. Phylogenetic analysis demonstrated close relationships in viruses from humans, animals and mosquitos in eastern Germany, obtained during the preceding 2 years. The described large cluster of autochthonous West Nile virus infections in Germany indicates endemic seasonal circulation of lineage 2 viruses in the area.

In August and September 2020, seven cases of West Nile neuroinvasive disease (WNND) and two cases of West Nile fever (WNF) were identified in patients at the Leipzig University Hospital, in eastern Germany. Five cases fulfilled the European Union case definitions for laboratory confirmed WNV infections and four cases were classified as probable WNV infections [1]. Here we describe the cases with their clinical characteristics and exact virological findings.

\section{Cases' characteristics}

Symptom onset in the seven male and two female cases occurred between 15 August and 9 September. All cases had geographic links to the city of Leipzig or to the surrounding district of Leipzig. None of them travelled abroad during the 4 weeks before symptom onset (Table 1). Six of the WNND cases were older than 60 years and three received immunosuppressive treatment. The WNND cases showed clinical, radiological, and laboratory features of meningitis, meningoencephalitis, encephalitis or acute flaccid paralysis. Additionally, fever, diarrhoea, rash, lymphadenopathy, renal failure, hepatitis and sepsis were observed. One case died (Table 1).

\section{Laboratory findings and phylogenetic analysis of genetic sequences}

A summary of laboratory findings is provided in Table 2. All cases showed positive results in WNV IgM ELISA (Euroimmun, Lübeck, Germany). Except for one of the cases receiving immunosuppressive medication, WNV IgG (Euroimmun) was either present in initial serum samples or seroconversion was documented by analysis of follow-up samples. Clinical samples from five cases revealed WNV RNA by real-time reverse-transcription PCR (RT-PCR) [2]. Of these, WNV RNA was found in urine in five cases, in serum in four and in cerebrospinal fluid (CSF) in one case. To demonstrate presence of infectious virus particles, WNV was isolated on Vero cells from three urine samples with high viral load [3].

The WNV-IgM positive sera were also tested for tick-borne encephalitis virus (TBEV) IgM antibodies (Euroimmun, Lübeck, Germany). The TBEV-IgM ELISA was non-reactive in all of them. TBEV-IgG was either negative $(n=3)$, high positive $(n=3)$ or low positive $(n=3)$. Thereof, all patients with history of TBE vaccination showed high TBEV-IgG titres. As no significant increase of the antibody titre was observed in follow-up samples of the low positive TBEV-IgG cases, the latter results were interpreted as probable crossreactivity of the assay with the present WNV-IgG or with any other pre-existing flavivirus antibodies, e.g. against Japanese encephalitis, Dengue or Yellow fever. All available CSF samples from the cases were negative for TBEV-RNA by real-time RT-PCR. 
TABLE 1

Characteristics of human West Nile virus infection cases $^{a}$, Leipzig, Germany, August-September $2020(\mathrm{n}=9)$

\begin{tabular}{|c|c|c|c|c|c|c|c|}
\hline Cases & $\begin{array}{c}\text { Case } \\
\text { classification }\end{array}$ & Disease & $\begin{array}{l}\text { Symptom } \\
\text { onset } \\
(2020)\end{array}$ & $\begin{array}{l}\text { Age } \\
\text { (years) }\end{array}$ & Recent travel & $\begin{array}{l}\text { Immunosuppressive } \\
\text { medication }\end{array}$ & Clinical manifestations \\
\hline Case 1 & Probable & WNND & Aug & $30-49$ & None & Yes $^{b}$ & $\begin{array}{c}\text { Fever, rash, lymphadenopathy, } \\
\text { headache, neck pain, phono- } \\
\text { and photophobia }\end{array}$ \\
\hline Case 2 & Confirmed & WNND & Aug & $80-89$ & $\begin{array}{l}\text { Federal State of } \\
\text { Brandenburg, } \\
\text { North-eastern } \\
\text { Germany }\end{array}$ & No & $\begin{array}{l}\text { Fever, sepsis, renal failure, } \\
\text { impaired consciousness }\end{array}$ \\
\hline Case 3 & Confirmed & WNND & Aug & $60-69$ & None & Yes $^{b}$ & $\begin{array}{l}\text { Fever, diarrhoea, headache, } \\
\text { impaired consciousness }\end{array}$ \\
\hline Case 4 & Confirmed & WNND & Aug & $70-79$ & None & No & $\begin{array}{c}\text { Fever, impaired consciousness, } \\
\text { seizures }\end{array}$ \\
\hline Case 5 & Confirmed & WNND & Aug & $70-79$ & None & Yes $^{\mathrm{b}}$ & $\begin{array}{c}\text { Fever, diarrhoea, vomiting, } \\
\text { orientation disorder, renal } \\
\text { failure, impaired consciousness }\end{array}$ \\
\hline Case 6 & Confirmed & WNND & Aug & $70-79$ & $\begin{array}{l}\text { Federal State of } \\
\text { Saxony-Anhalt, } \\
\text { Central Germany }\end{array}$ & No & $\begin{array}{l}\text { Fever, diarrhoea, renal failure, } \\
\text { hepatitis, tetraplegia, persistent } \\
\text { coma, death }\end{array}$ \\
\hline Case 7 & Probable & WNND & Sep & $60-70$ & None & No & $\begin{array}{l}\text { Acute flaccid paralysis of the } \\
\text { lower extremities }\end{array}$ \\
\hline Case 8 & Probable & WNF & Sep & $30-39$ & $\begin{array}{l}\text { Leipzig District, } \\
\text { Western Saxony }\end{array}$ & No & $\begin{array}{l}\text { Rash, nausea, diarrhoea, head } \\
\text { and body aches, photophobia }\end{array}$ \\
\hline Case 9 & Probable & WNF & Sep & $10-20$ & $\begin{array}{l}\text { Leipzig District, } \\
\text { Western Saxony }\end{array}$ & No & $\begin{array}{l}\text { Rash, nausea, diarrhoea, head } \\
\text { and body aches, photophobia }\end{array}$ \\
\hline
\end{tabular}

WNF: West Nile fever; WNND: West Nile neuroinvasive disease.

${ }^{a}$ Five confirmed and four probable cases according to the European Union case definition [1].

${ }^{\mathrm{b}}$ Azathioprine or prednisolone.

TABLE 2

Virological data of human West Nile virus infection cases ${ }^{a}$, Leipzig, Germany, August-September $2020(\mathrm{n}=9)$

\begin{tabular}{|l|c|c|c|c|c|c|c|c|} 
Cases & $\begin{array}{c}\text { Time to } \\
\text { diagnosis } \\
\text { (days) }^{\mathrm{b}}\end{array}$ & WNV IgM & WNV IgG & $\begin{array}{c}\text { WNV RNA in } \\
\text { urine (GE/mL) }\end{array}$ & $\begin{array}{c}\text { WNV RNA in } \\
\text { serum (GE/mL) }\end{array}$ & $\begin{array}{c}\text { WNV RNA in } \\
\text { CSF (GE/mL) }\end{array}$ & $\begin{array}{c}\text { WNV cell- } \\
\text { culture } \\
\text { isolation }\end{array}$ & $\begin{array}{c}\text { WNV } \\
\text { lineage }\end{array}$ \\
\hline Case 1 & 8 & Positive & Sero-conversion & Undetectable & Undetectable & Undetectable & ND & ND \\
\hline Case 2 & 6 & Positive & Positive & $1,010,000$ & 1,000 & Undetectable & Positive & 2 \\
\hline Case 3 & 6 & Positive & Negative & 500 & 200 & Undetectable & ND & 2 \\
\hline Case 4 & 6 & Positive & Sero-conversion & 100 & Undetectable & Undetectable & ND & 2 \\
\hline Case 5 & 6 & Positive & Positive & $6,450,000$ & 150 & Undetectable & Positive & 2 \\
\hline Case 6 & 7 & Positive & Sero-conversion & $67,200,000$ & 5,200 & 1,500 & Positive & 2 \\
\hline Case 7 & 8 & Positive & Positive & Undetectable & Undetectable & Undetectable & ND & ND \\
\hline Case 8 & 5 & Positive & Sero-conversion & Undetectable & Undetectable & ND & ND & ND \\
\hline Case 9 & 12 & Positive & Positive & Undetectable & Undetectable & ND & ND & ND \\
\hline
\end{tabular}

CSF: cerebrospinal fluid; GE: genome equivalents; ND: not determined; WNV: West Nile virus.

${ }^{a}$ Five confirmed and four probable cases according to the European Union case definition [1].

${ }^{\mathrm{b}}$ This is the time between symptom onset and the day of first sample collection.

' WNV IgG was still undetectable at the last day of follow-up (20 days after symptom onset). 


\section{FIGURE 1}

Phylogenetic analysis of almost complete WNV lineage 2 genomes (11,005 nt)

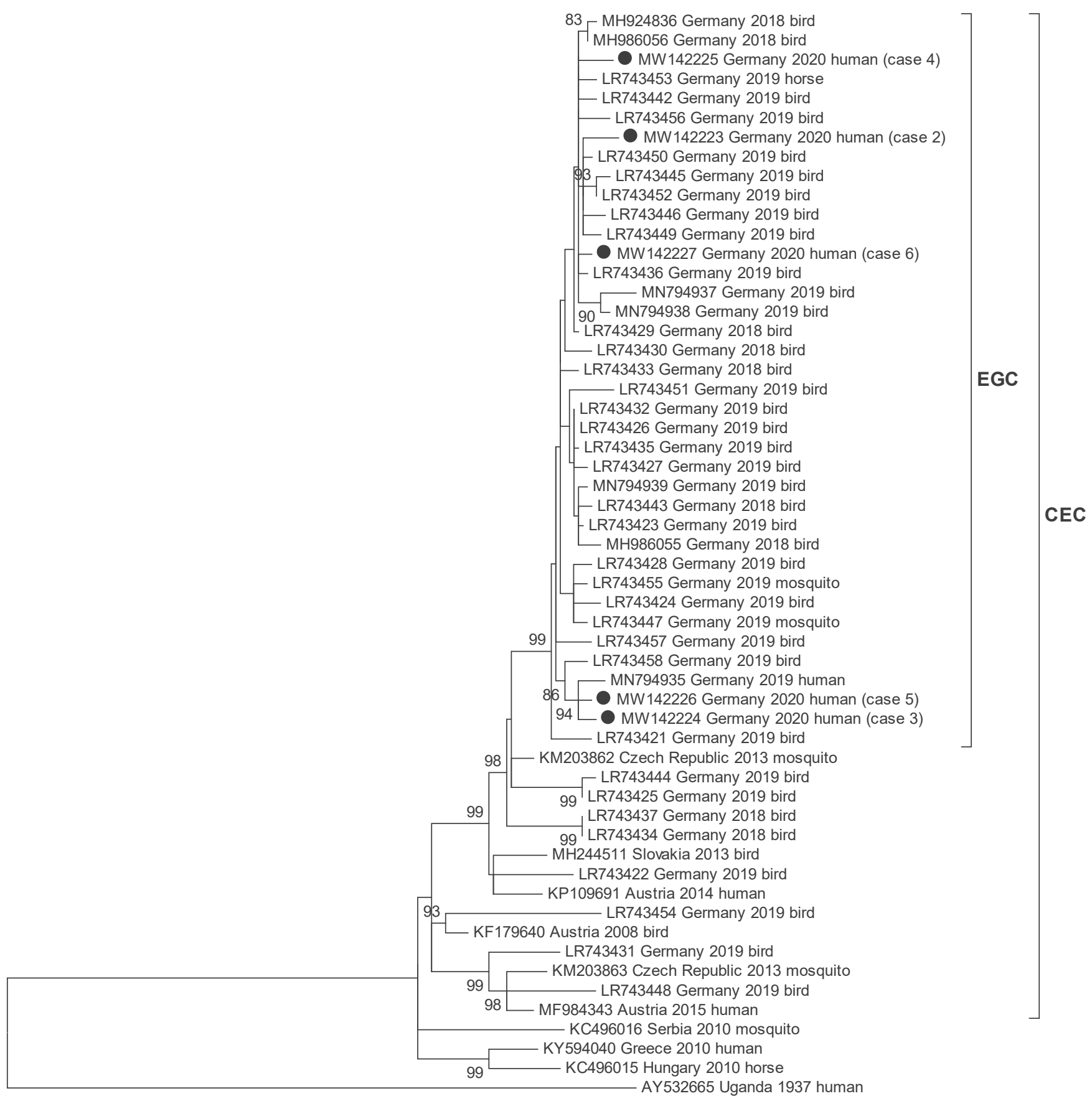

0.002 substitutions per nt

CEC: Central and Eastern European clade; EGC: Eastern German clade; nt: nucleotides; WNV: West Nile virus.

All WNV strains sequenced in this study are indicated by filled circles and are part of the main CEC - which includes the EGC as proposed earlier by Ziegler et al. [17]. Nucleotide identity between the present WNV lineage 2 genomes was $99.8-99.9 \%$. The evolutionary history was inferred by using the Maximum Likelihood method based on the Tamura-Nei model. GenBank accession numbers of included sequences are shown on the tree. The scale bar indicates nt substitutions per site. Bootstraps values above $80 \%$ are shown next to the branches. 


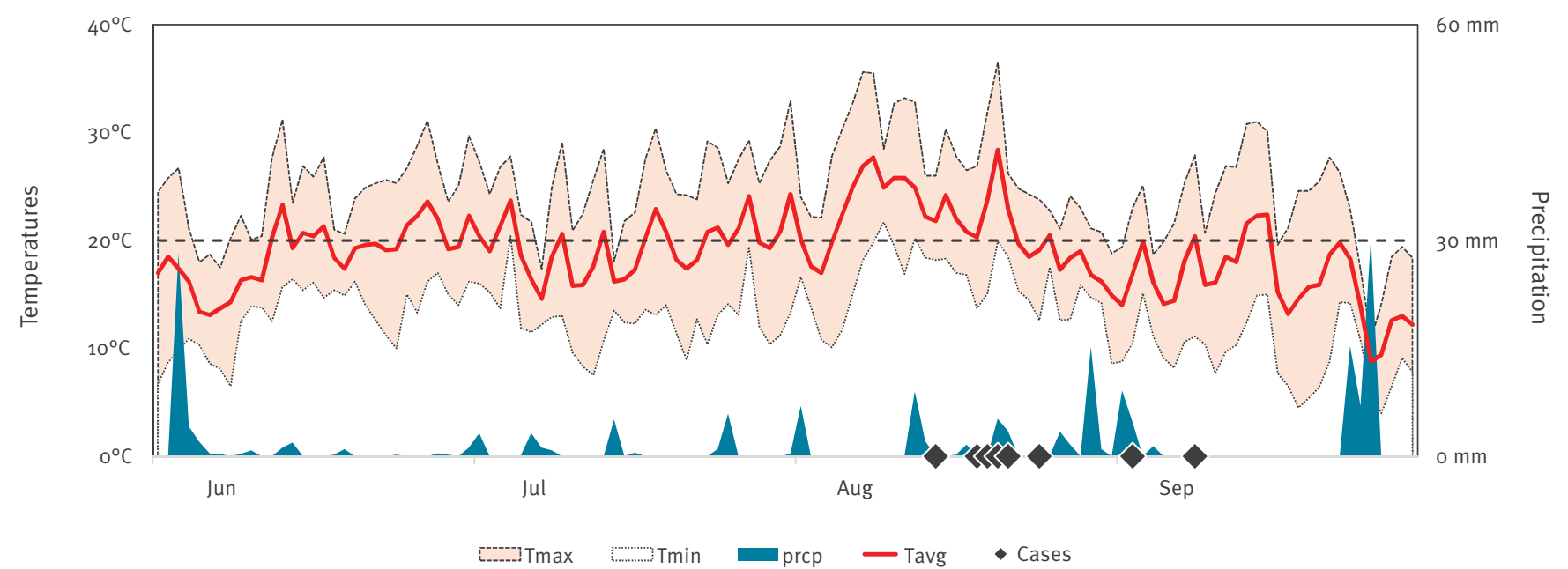

Daily average temperatures (Tavg), maximum temperatures (Tmax), minimum temperatures (Tmin) and precipitation (prcp) from June to September 2020 are shown. Source: meteostat.net. Black diamonds indicate the days of symptom onset of the West Nile virus infection cases.

Full-coding viral genomes were assessed using Sanger sequencing and primer walking for four of the WNV cases with detectable viral RNA. Due to the very low viral load, only partial genome sequences were derived from the fifth one (GenBank accession numbers

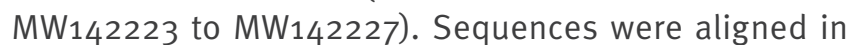
Geneious Prime software (Biomatters, Auckland, New Zealand). Phylogenetic analysis was conducted using MEGA 5 [4]. All obtained genome sequences showed lineage 2 viruses. Phylogenetic analysis demonstrated their close genetic relationship to viral strains detected in humans, birds and horses in eastern Germany during the 2 preceding years (Figure 1 ).

\section{Meteorological parameters and environmental situation in the city of}

\section{Leipzig}

Leipzig is a city of 600,000 inhabitants in centraleastern Germany and belongs to the Federal State of Saxony. Overall, Leipzig has a temperate seasonal climate with relatively mild winters and warm rather than hot summers. The warmest month, on average, is July with an average temperature of $18^{\circ} \mathrm{C}$ (Leipzig Institute for Meteorology, Faculty of Physics and Earth Sciences, Leipzig University). In 2020, there was a heat wave with average daily temperatures above $20^{\circ} \mathrm{C}$ from 6 August to 22 August. In parallel, precipitation was below average (ca $60 \mathrm{~mm}$ ) with a monthly accumulated rainfall of $22.2 \mathrm{~mm}$ and $50.1 \mathrm{~mm}$ in July and August, respectively (Figure 2).

Irrespectively of the dry period in summer 2020, the Leipzig urban area provides multiple natural freshwater habitats for mosquitoes such as wetlands, large alluvial forests, park ponds, confluent rivers, large pit lakes, and numerous allotment gardens.

\section{Ethical statement}

The Leipzig University Ethics Committee approved the study (no. AZ 298/16 [ek). Only anonymous patient and ward data are presented to protect the patients' identity.

\section{Discussion and conclusions}

West Nile virus is maintained in nature through an enzootic bird-mosquito cycle. Transmitted by different species of Culex mosquitoes, it can affect a wide range of accidental hosts such as horses and humans. Different lineages are circulating [5]. In 2004, WNV lineage 2 emerged in Europe [6]. Today, WNV lineage 2 is endemic in many European countries and causes seasonal regional outbreaks with increasing frequency $[7,8]$.

Imported WNV infections were observed earlier in Germany $[9,10]$, but autochthonous transmission of WNV in the country was diagnosed as late as in 2018 for the first time, in resident birds and horses in central-eastern Germany [11]. Prior to that, the virus had been detected neither in potential reservoir species nor in vectors in spite of a comprehensive nationwide wild bird surveillance system $[12,13]$ and an exhaustive mosquito surveillance programme for zoonotic arthropod-borne viruses [14-16]. The number of WNVpositive birds and horses rose considerably in 2019 and five autochthonous human WNV infection cases were observed [17]. At the same time, WNV was demonstrated in indigenous Culex spp [18]. The areas with highest activity of WNV were the German Federal States of Saxony, Saxony-Anhalt, Brandenburg and Berlin, i.e. central-eastern Germany [17]. Notably, all autochthonous human cases occurred in this region - three of them in the municipal area of Leipzig [17]. All genetically characterised viruses detected from human and animal cases and vectors in 2018 and 2019, showed 
close phylogenetic links to the Eastern European clade of WNV lineage 2 viruses [17].

In contrast to the five sporadic human WNV cases detected in 2019, the presented cluster of nine autochthonous WNND and WNF cases was detected at a single hospital within an observation period of less than 4 weeks. Based on the cases' place of residence and travel history, the presence of an endemic cycle in local species of birds and mosquitos in the city of Leipzig has to be assumed. This assumption is also supported by the common spatial link between human WNV cases in 2020 and 2019. Furthermore, phylogenetic analysis demonstrated that WNV in central-eastern Germany has maintained genetically stable since the first detection in 2018. This makes new WNV introductions via migratory birds an unlikely scenario and rather indicates WNV lineage 2 persistence in resident reservoir bird species or hibernating mosquitoes.

The present cases occurred in late summer after a distinct hot and dry period. It is known that high daily average temperatures $\left(>20^{\circ} \mathrm{C}\right)$ over several days are required to allow for efficient WNV transmission [19]. Thus, the 2020 summer heat wave presumably drove the epizootic emergence of the virus in Leipzig by shortening the extrinsic incubation period of the virus in the vector mosquitoes. In addition, increased WNV activity is rather related to dry conditions than to rainy periods [20]. Among others, a possible reason for this is the congregation of reservoir host birds around dwindling water sources, which increases the rates of contact between avian reservoirs and mosquitoes and thereby virus transmission [20].

There was a wide age-range among our cases. Advanced age remains a major risk factor for disease caused by WNV and individuals older than 50 years of age are more susceptible to severe infections with neurological involvement [5]. Accordingly, the majority of the WNND cases documented here occurred among people aged 60 years and older. Given that less than $1 \%$ of infected humans develop WNND [5], it seems reasonable to assume that the local outbreak of WNV infections may have affected several hundred people. Presumably, most of them developed only minor or no clinical symptoms at all. This assumption is well supported by the fact that WNV infections have recently been identified in asymptomatic blood donors in the area [21].

In conclusion, the presented WNV infections cluster represents so far the largest outbreak of autochthonous human cases in Germany, to the best of our knowledge. An endemic seasonal circulation of WNV lineage 2 viruses in the city of Leipzig and the surrounding districts has to be assumed. During the coming summers, epizootic re-emergence of the virus and increasing case numbers in humans are possible. Therefore, awareness of human WNV infections should be further increased in the general population and among healthcare workers i.e. neurologists, internists and general practitioners, by education programmes. Moreover, in the authors' opinion, existing surveillance programmes for birds and mosquitoes should be expanded and intensified in Leipzig and the surrounding districts.

\section{Conflict of interest}

None declared.

\section{Authors' contributions}

Corinna Pietsch: lead and corresponding author, direction of data collection, data analysis, epidemiological and public health perspective. Dominik Michalski, Johannes Münch, Sirak Petros, Henning Trawinski, Christoph Lübbert: clinical case management and description. Sandra Bergs: virological testing and genetic characterisation of viral genomes. Uwe G. Liebert: supervising of the project and co-authoring of manuscript. All authors discussed the results and contributed to the final manuscript.

\section{References}

1. European Commission. European Commission implementing decision of 8 August 2012 amending Decision 2002/253/ EC laying down case definitions for reporting communicable diseases to the Community network under Decision No 2119/98/EC of the European Parliament and of the Council. 27.9.2012:L 262. Official Journal of the European Union. Luxembourg: Publications Office of the European Union. 27 Sep 2012. Available from: http://eur-lex.europa.eu/LexUriServ/ LexUriServ.do?uri=0J:L:2012:262:0001:0057:EN:PDF

2. Eiden M, Vina-Rodriguez A, Hoffmann B, Ziegler U, Groschup $\mathrm{MH}$. Two new real-time quantitative reverse transcription polymerase chain reaction assays with unique target sites for the specific and sensitive detection of lineages 1 and 2 West Nile virus strains. Journal of veterinary diagnostic investigation: official publication of the American Association of Veterinary Laboratory Diagnosticians. Inc.2010;22(5):748-53.

3. Barzon L, Pacenti M, Franchin E, Squarzon L, Sinigaglia $A$, Ulbert $S$, et al. Isolation of West Nile virus from urine samples of patients with acute infection. J Clin Microbiol. 2014;52(9):3411-3. https://doi.org/10.1128/JCM.01328-14 PMID: 24951801

4. Tamura K, Peterson D, Peterson N, Stecher G, Nei M, Kumar S. MEGA5: molecular evolutionary genetics analysis using maximum likelihood, evolutionary distance, and maximum parsimony methods. Mol Biol Evol. 2011;28(10):2731-9. https://doi.org/10.1093/molbev/msr121 PMID: 21546353

5. Gray TJ, Webb CE. A review of the epidemiological and clinical aspects of West Nile virus. Int J Gen Med. 2014;7:193-203. https://doi.org/10.2147/IJGM.S59902 PMID: 24748813

6. Bakonyi T, Hubálek Z, Rudolf I, Nowotny N. Novel flavivirus or new lineage of West Nile virus, central Europe. Emerg Infect Dis. 2005;11(2):225-31. https://doi.org/10.3201/ eid1102.041028 PMID: 15752439

7. Camp JV, Nowotny N. The knowns and unknowns of West Nile virus in Europe: what did we learn from the 2018 outbreak? Expert Rev Anti Infect Ther. 2020;18(2):145-54. https://doi.org /10.1080/14787210.2020.1713751 PMID: 31914833

8. Bakonyi T, Ferenczi E, Erdélyi K, Kutasi O, Csörgő T, Seidel B, et al. Explosive spread of a neuroinvasive lineage 2 West Nile virus in Central Europe, 2008/2009. Vet Microbiol. 2013;165(1 2):61-70. https://doi.org/10.1016/j.vetmic.2013.03.005 PMID: 23570864

9. Schultze-Amberger J, Emmerich P, Günther S, SchmidtChanasit J. West Nile virus meningoencephalitis imported into Germany. Emerg Infect Dis. 2012;18(10):1698-700. https://doi. org/10.3201/eid1810.120204 PMID: 23017806

10. Pietsch C, Trawinski H, Lübbert C, Liebert UG. Short Communication: West Nile fever imported from Austria to Germany. Transbound Emerg Dis. 2019;66(2):1033-6. https:// doi.org/10.1111/tbed.13079 PMID: 30462884 
11. Ziegler U, Lühken R, Keller M, Cadar D, van der Grinten E, Michel F, et al. West Nile virus epizootic in Germany, 2018. Antiviral Res. 2019;162:39-43. https://doi.org/10.1016/j. antiviral.2018.12.005 PMID: 30550796

12. Michel F, Sieg M, Fischer D, Keller M, Eiden M, Reuschel M, et al. Evidence for West Nile Virus and Usutu Virus Infections in Wild and Resident Birds in Germany, 2017 and 2018. Viruses. 2019;11(7):E674. https://doi.org/10.3390/v11070674 PMID: 31340516

13. Michel F, Fischer D, Eiden M, Fast C, Reuschel M, Müller K, et al. West Nile Virus and Usutu Virus Monitoring of Wild Birds in Germany. Int J Environ Res Public Health. 2018;15(1):E171. https://doi.org/10.3390/ijerph15010171 PMID: 29361762

14. Scheuch DE, Schäfer M, Eiden M, Heym EC, Ziegler U, Walther $D$, et al. Detection of Usutu, Sindbis, and Batai Viruses in Mosquitoes (Diptera: Culicidae) Collected in Germany, 2011-2016. Viruses. 2018;10(7):E389. https://doi.org/10.3390/ V10070389 PMID: 30041410

15. Heym EC, Kampen H, Krone O, Schäfer M, Werner D. Molecular detection of vector-borne pathogens from mosquitoes collected in two zoological gardens in Germany. Parasitol Res. 2019;118(7):2097-105. https://doi.org/10.1007/s00436-01906327-5 PMID: 31154526

16. Ziegler U, Fischer D, Eiden M, Reuschel M, Rinder M, Müller K, et al. Sindbis virus- a wild bird associated zoonotic arbovirus circulates in Germany. Vet Microbiol. 2019;239:108453. https://doi.org/10.1016/j.vetmic.2019.108453 PMID: 31767092

17. Ziegler U, Santos PD, Groschup MH, Hattendorf C, Eiden M, Höper D, et al. West Nile Virus Epidemic in Germany Triggered by Epizootic Emergence, 2019. Viruses. 2020;12(4):E448. https://doi.org/10.3390/v12040448 PMID: 32326472

18. Kampen H, Holicki CM, Ziegler U, Groschup MH, Tews BA, Werner D. West Nile Virus Mosquito Vectors (Diptera: Culicidae) in Germany. Viruses. 2020;12(5):E493. https://doi. org/10.3390/v12050493 PMID: 32354202

19. Holicki CM, Ziegler U, Răileanu C, Kampen H, Werner D, Schulz J, et al. West Nile Virus Lineage 2 Vector Competence of Indigenous Culex and Aedes Mosquitoes from Germany at Temperate Climate Conditions. Viruses. 2020;12(5):12. https:// doi.org/10.3390/v12050561 PMID: 32438619

20. Paull SH, Horton DE, Ashfaq M, Rastogi D, Kramer LD, Diffenbaugh NS, et al. Drought and immunity determine the intensity of West Nile virus epidemics and climate change impacts. Proceedings Biological sciences / The Royal Society.1848;2017:284

21. Robert Koch Institute (RKI). Aktuelle Situation zu autochthonen menschlichen Infektionen mit dem West-Nil-Virus in Deutschland 2020. [Current situation of autochthonous human infections with West Nile virus in Germany 2020]. Epid Bull. 2020;37. German. Available from: https://www.rki.de/ DE/Content/Infekt/EpidBull/Archiv/2020/Ausgaben/3720. pdf?__blob=publicationFile

\section{License, supplementary material and copyright}

This is an open-access article distributed under the terms of the Creative Commons Attribution (CC BY 4.0) Licence. You may share and adapt the material, but must give appropriate credit to the source, provide a link to the licence and indicate if changes were made.

Any supplementary material referenced in the article can be found in the online version.

This article is copyright of the authors or their affiliated institutions, 2020. 